\title{
No rat poison for me
}

\author{
Tsuyoshi Kaneko, MD, and Sary F. Aranki, MD
}

From the Division of Cardiac Surgery, Brigham and Women's Hospital, Boston, Mass Disclosures: Authors have nothing to disclose with regard to commercial support. Received for publication June 23, 2017; accepted for publication July 6, 2017.

Address for reprints: Sary F. Aranki, MD, 75 Francis St, Boston, MA 02115 (E-mail: saranki@ partners.org). J Thorac Cardiovasc Surg 2017;154:1542-3

$0022-5223 / \$ 36.00$

Copyright (c) 2017 Published by Elsevier Inc. on behalf of The American Association for Thoracic Surgery http://dx.doi.org/10.1016/j.jtcvs.2017.07.009

In this edition of the Journal, Anselmi and associates ${ }^{1}$ report on the long-term outcomes of bioprosthetic valves in younger patients. The authors identified 416 patients aged 60 years or less who underwent bioprosthetic aortic valve replacement (AVR) with $98.5 \%$ complete followup. Overall survival at 15 years was $62.1 \% \pm 4.4 \%$, but freedom from valve-related death was $97.1 \% \pm 1.6 \%$. Freedom from structural valve deterioration (SVD) was $48.5 \% \pm 5.5 \%$ in the actuarial analysis and $61.4 \% \pm 4.3 \%$ when calculated using competing risks. When stratified by different age groups, no significant differences in freedom from SVD were observed. Freedom from SVD was greater than $80 \%$ at 10 years, and most occurred after the first decade of implantation.

There has been a significant increase of bioprosthetic valves use in recent years. Brown and colleagues ${ }^{2}$ reported on 108,687 isolated AVRs over a 10-year period from the Society of Thoracic Surgeons database. Bioprosthetic use increased from $43.6 \%$ in 1997 to $78.4 \%$ in 2006 (Figure 1). Similar trends were seen at our institution (Figure 2, A), with an increase from $20 \%$ to more than $60 \%$ in patients aged less than 60 years (Figure 2, B).

What is driving younger patients to choose a bioprosthesis apart from the medical contraindications for anticoagulation? Increasing motive is the pursuit of active lifestyle. The momentum of valve choice seems to have shifted from physician recommendation to patient preference. An important aspect of valve choice is increased patient awareness from information gathered online. ${ }^{3}$ Oftentimes, we see a patient who has already decided on the valve type by using an Internet search and discussing it with the referring cardiologist. Their decision is based on a simple formula: comparing the risk of a repeat AVR versus the risk of taking anticoagulation for 10 years or more. From a large Society of Thoracic Surgeons database study, the operative mortality of repeat AVR was $4.9 \% .{ }^{4}$ In one study, the simulated lifetime risk of bleeding was $41 \%$ for a 60 -year-old man. ${ }^{5}$ Warfarin also is associated with difficulty controlling the international normalized ratio (INR) within the therapeutic level, described by using the term "time within therapeutic range (TTR)." One study showed that in the first 6 months of initiating warfarin, TTR was

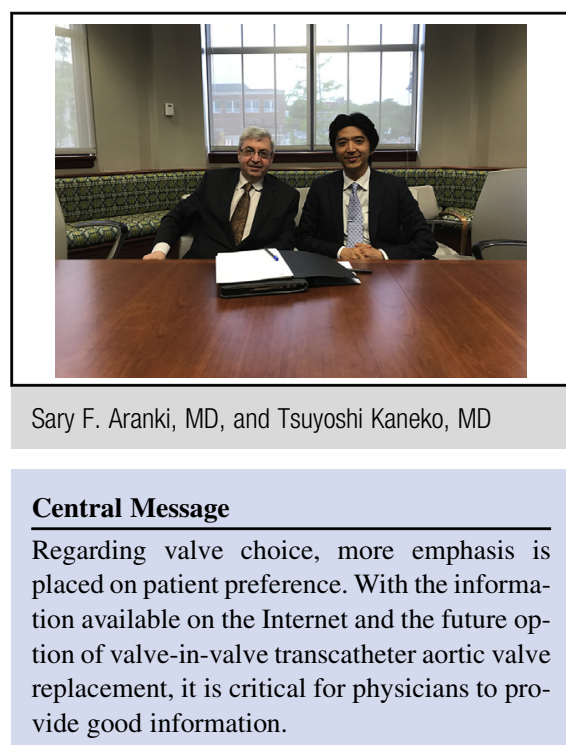

See Article page 1534.

only $32 \% .{ }^{6}$ Patients who are not in TTR are exposed to bleeding risk if INR is higher or thromboembolism if INR is lower. This leads to the fact that warfarin is the top reason $(33 \%)$ for emergency hospitalizations for drug events in older Americans. ${ }^{7}$

In addition, the valve-in-valve transcatheter aortic valve replacement option has changed the landscape in the patient's decision. Despite the uncertainty of valve durability or valve thrombosis after valve-in-valve transcatheter aortic valve replacement, avoidance of reoperation is a strong factor in valve choice.

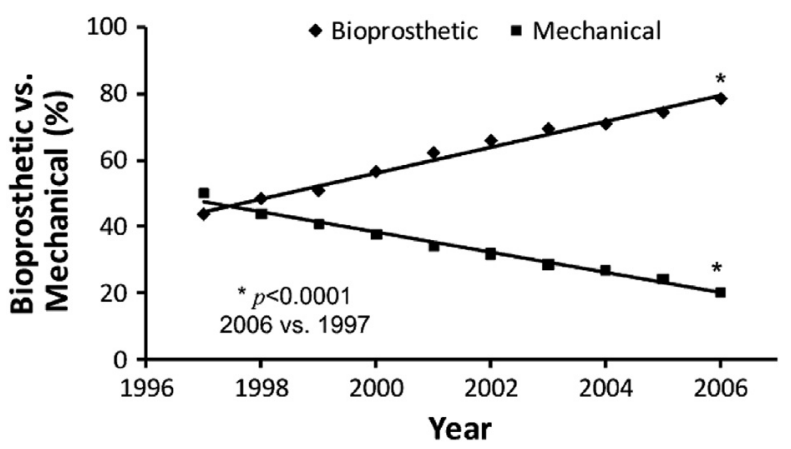

FIGURE 1. Use of bioprosthetic valve versus mechanical valve in North America comprising 108,687 patients in 10 years from the Society of Thoracic Surgeons National Database. Reprinted with permission. ${ }^{2}$ 


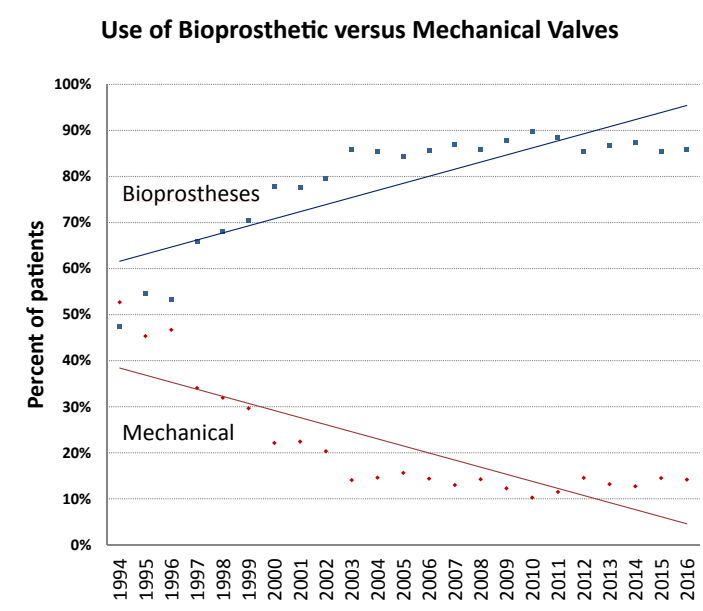

\section{A}

FIGURE 2. A, The use of mechanical and bioprosthesis at the Brigham and Women's Hospital. B, The ratio of bioprosthetic valve use by different age groups at the Brigham and Women's Hospital.

At the end of the day, one cannot argue with current statistics about valve choices. It is patient preference rather than surgeon recommendation that is driving this trend. Nevertheless, it is still crucial for physicians to provide good information to aid the understanding of true risks and benefits. We hope this and similar studies serve as a guide to patients' decisions and expectations.

\section{References}

1. Anselmi A, Flecher E, Chabanne C, Ruggieri VG, Langanay T, Corbineau H, et al. Long-Term follow-up of bioprosthetic aortic valve replacement in patients aged 60 years or less. J Thorac Cardiovasc Surg. 2017;154:1534-41.e4.

2. Brown JM, O'Brien SM, Wu C, Sikola JH, Griffith BP, Gammie JS. Isolated aortic valve replacement in North America comprising 108,687 patients in 10 years: changes in risks, valve types, and outcomes in the Society of Thoracic Surgeons National Database. J Thorac Cardiovasc Surg. 2009;137:82-90.

3. Kaneko T, Cohn LH, Aranki SF. Tissue valve is the preferred option for patients aged 60 and older. Circulation. 2013;128:1365-71.

4. Kaneko T, Vassileva CM, Englum B, Kim S, Yammine M, Brennan M, et al Contemporary outcomes of repeat aortic valve replacement: a benchmark for transcatheter valve-in-valve procedures. Ann Thorac Surg. 2015;100:1298-304.

5. van Geldorp MWA, Jamieson WRE, Kappetein AP, Ye J, Fradet GJ Eijkemans MJC, et al. Patient outcome after aortic valve replacement with a mechanical or biological prosthesis: weighing lifetime anticoagulant-related event

6. Beyth RJ, Quinn L, Landefeld CS. A multicomponent intervention to prevent major bleeding complications in older patients receiving warfarin. A randomized, controlled trial. Ann Intern Med. 2000;133:687-95.

7. Budnitz DS, Lovegrove MC, Shehab N, Richards CL. Emergency hospitalizations for adverse drug events in older Americans. N Engl J Med. 2011;365: 2002-12. risk against reoperation risk. J Thorac Cardiovasc Surg. 2009;137:881-6. 